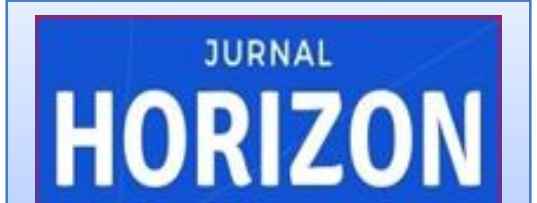

PENDIDIKAN

Publish by: Library of STKIP PGRI Sumatera Barat

E-ISSN : 2775-5770

Vol. 1 No. 4 (November 2021) (724-732)

http://ejournal.stkip-pgri-sumbar.ac.id/index.php/horizon

\title{
ANALISIS FAKTOR PENYEBAB KESULITAN BELAJAR SISWA \\ DALAM PEMBELAJARAN MATEMATIKA KELAS XIIPS 4 SMA NEGERI 2 SUNGAI LIMAU
}

Irma Dian Pratama, Dewi Yuliana Fitri, Lita Lovia

Program Studi Pendidikan Matematika STKIP PGRI Sumatera Barat irmadianpratama2676gmail.com

Submitted: 08-09-2021, Reviewed: 07-10-2021, Accepted: 09-11-2021

\begin{abstract}
This research is motivated by the low learning outcomes of students' mathematics. Low learning outcome are characteristics of students experiencing obstacles or obstacles during the learning process. This research aims to describe and analyze the factors that cause students' learning difficulties in mathematics. The sample of this study amounted to 32 students of class XI IPS 4 SMA Negeri 2 Sungai Limau. The type of research used is descriptive research with a qualitative approach. The instrument used a learning difficulty questionnaire, interview sheets and documentation to strengthen the results of the questionnaire answers. The data analysis technique of this research is the analysis of questionnaires and interviews. The results of this study indicate that: 1) internal factors that affect learning difficulties are described as follows, in the indicator of readiness in learning as much as $71.8 \%$ in the category of very influential on the learning process, on motivation indicators as much as $29 \%$ in the category of being quite influential in the learning process, on the indicator of interest as much as 53\% with the category influential in the mathematics learning process and the health indicator as much as $50.6 \%$ with the category having an effect on learning mathematics. 2) external factors that affect learning difficulties in mathematics are as follows, indicators of family factors in learning as much as $37.5 \%$ with a category that is quite influential on the mathematics learning process, on school indicators as much as $51.5 \%$ with categories that affect the online learning process and on environmental indicators community as much as $39.6 \%$ with the category quite influential on the student learning process.
\end{abstract}

Keywords: Analysis, Learning Difficulty factor, Mathematics.

\section{PENDAHULUAN}

Belajar merupakan suatu usaha yang dilakukan seseorang untuk dapat memperoleh suatu perubahan tingkah laku yang baru secara keseluruhan sebagai hasil pengalaman sendiri dalam interaksi dengan lingkungannya Slameto (2010: 2). Berdasarkan definisi di atas, dapat disimpulkan bahwa siswa dikatakan telah mengalami proses belajar jika telah terjadi perubahan perilaku pada dirinya yang bertujuan untuk mendapatkan hasil dari 


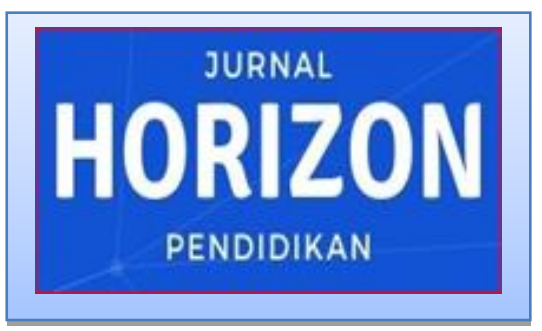

JURNAL HORIZON PENDIDIKAN

Publish by: Library of STKIP PGRI Sumatera Barat

E-ISSN : 2775-5770

Vol. 1 No. 4 (November 2021) (724-732) http://ejournal.stkip-pgri-sumbar.ac.id/index.php/horizon

pengalaman dirinya sendiri dalam berinteraksi dengan lingkungannya. Dengan demikian inti dari belajar adalah proses perubahan seseorang dalam aspek pengetahuan, sikap, keterampilan, dan kebiasaan sehingga mampu berinteraksi dengan lingkungan. Matematika merupakan pelajaran yang memiliki peranan penting dalam meningkatkan kemajuan ilmu pengetahuan dan teknologi (IPTEK). Ketercapaian pembelajaran matematika dapat dilihat dari siswa mampu menyelesaikan tugas-tugas belajar matematika, menjadikan matematika bagian penting dalam kehidupan siswa, rendahnya hasil belajar merupakan salah satu ciri-ciri siswa mengalami kesulitan belajar.

Kesulitan belajar siswa biasanya tampak ketika menurunnya prestasi belajar atau kinerja akademik. Akan tetapi kesulitan belajar juga dapat dilihat dari sikap siswa saat pembelajaran berlangsung. Kesulitan juga dialami siswa kelas X IPS 4 SMA Negeri 2 Sungai Limau. Hasil wawancara dengan guru matematika masih banyak dari siswa yang kesulitan memahami materi pelajaran matematika, hal ini terlihat dari banyaknya siswa kesulitan dalam menyelesaikan soal yang mengakibatkan nilai belum mencapai Kriteria Ketuntasan Minimal (KKM). Dalam proses pembelajaran guru sulit membuat siswa untuk bisa fokus pada saat pembelajaran berlangsung. Metode digunakan guru saat pembelajaran lebih sering menggunakan metode ceramah. Berdasarkan hasil wawancara dengan siswa, siswa senang jika jam mata pelajaran matematika kosong. Siswa juga jarang membuka kembali materi matematika yang telah diajarkan. Siswa juga mengatakan bahwa matematika dipandang sebagai mata pelajaran yang sulit, karena matematika memiliki rumus yang susah untuk dipahami, apalagi dengan keadaan pembelajaran tatap muka masa pandemi dengan waktu jam pembelajaran yang berkurang daridari jam pelajaran biasanya, sehingga siswa malas untuk mengikuti pelajaran matematika.

\section{METODE PENELITIAN}

Penelitian ini adalah penelitian deskriptif dengan metode kuantitatif 
HORIZON

PENDIDIKAN

Publish by: Library of STKIP PGRI Sumatera Barat

E-ISSN : 2775-5770

Vol. 1 No. 4 (November 2021) (724-732) http://ejournal.stkip-pgri-sumbar.ac.id/index.php/horizon

yang bertujuan mengungkapkan suatu apa adanya pada saat penelitian dilakukan. Menurut Arikunto (2010: 65) penelitian deskriptif tidak dimaksudkan untuk menguji hipotesis tertentu, tetapi hanya menggambarkan apa adanya tentang suatu variabel.

Teknik yang digunakan dalam pengambilan subjek penelitian yaitu teknik purposive sampling. Teknik purposive sampling merupakan metode penetapan siswa untuk dijadikan sampel berdasarkan kriteria-kriteria tertentu (Siregar, 2014). Jadi dapat dikatakan purposive sampling yaitu menentukan subjek atau objek sesuai dengan tujuan penelitian. Kelas subjek yang dipilih yakni siswa kelas XI IPS 4 SMA Negeri 2 Sungai Limau. Jadi sampel untuk angket penelitian ini berjumlah 32 orang.

Instrumen yang digunakan dalam penelitian ini yaitu instrumen nontes berupa daftar pertanyaan angket,wawancara dan dokumentasi.

Angket yang digunakan yaitu angket dengan pernyataan tertutup, pernyataan tertutup akan membantu responden untuk menjawab dengan cepat, dan juga memudahkan peneliti dalam melakukan analisis data terhadap seluruh angket yag telah terkumpul. Metode angket dalam penelitian ini digunakan untuk menggambarkan faktor penyebab kesulitan belajar siswa dalam pembelajaran matematika.

Angket yang digunakan yaitu angket dengan skala guttman (Zarkasyi, 2015). Angket tersebut disusun dengan dua pilihan yaitu "ya" dan "tidak". Pengambilan data dilakukan dengan cara memberi tanda check list yang sesuai dengan item pernyataan menggunakan angket skala guttman untuk mendapatkan jawaban yang jelas dengan dua alternatif jawaban yaitu "ya" dan "tidak", dimana untuk jawaban pernyataan positif untuk pilihan "ya" diberi skor 0 dan pilihan “tidak" diberi skor 1, sedangkan untuk jawaban pernyataan negatif untuk pilihan "ya" diberi skor 1 dan pilihan "tidak" diberi skor 0. Adapun skoring perhitungan responden dalam skala Guttman adalah sebagai berikut : 


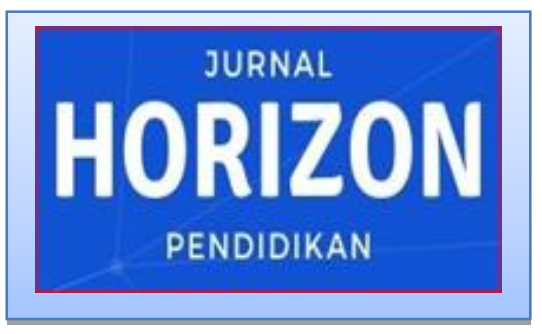

JURNAL HORIZON PENDIDIKAN

Publish by: Library of STKIP PGRI Sumatera Barat

E-ISSN : 2775-5770

Skoring Skala Guttman

\begin{tabular}{llc}
\hline Alternatif & \multicolumn{2}{l}{ Skor Alternatif Jawaban } \\
Jawaban & Positif & Negatif \\
Ya & 0 & 1 \\
Tidak & 1 & 0
\end{tabular}

Jawaban pernyataan positif pilihan "ya" dapat diartikan bukan penyebab kesulitan belajar siswa saat mengikuti pembelajaran dan pilihan "tidak" diartikan sebagai penyebab kesulitan belajar siswa saat mengikuti pembelajaran. Sedangkan jawaban pernyataan negatif pilihan "ya" dapat diartikan sebagai penyebab kesulitan belajar siswa saat mengikuti mata pembelajaran danpilihan "tidak" dapat diartikan bukan penyebab kesulitan belajar saat mengikuti mata pelajaran matematika. sebelum angket diberikan kepada peserta didik angket divalidasi dulu sama guru pembelajaran matematika.

Analisis data dalam suatu penelitian yang akan merupakan pokok utama dalam sebuah penelitian karena dengan melakukan analisis akan dapat diperoleh hasil dari apa yang menyebabkan kesulitan belajar siswa dalam pembelajaran matematika

berdasarkan

Vol. 1 No. 4 (November 2021) (724-732) kelompoknya melalui angket dan wawancara :

1. Angket

Angket merupakan teknik pengumpulan data yang dilakukan dengan cara memberi seperangkat pertanyaan atau pertanyaan tertulis kepada responden untuk dijawabnya (Fauziah, 2017). Instrumen penelitian ini menggunakan angket dengan memberikan seperangkat pernyataan untuk mengetahui faktor internal dan eksternal yang mempengaruhi kesulitan belajar dalam pembelajaran matematika kelas XI IPS 4 SMA Negri 2 Sungai Limau. Adapun teknik statistik yang digunakan dalam penelitian ini adalah persentase. Persentase untuk setiap kemungkinan jawaban diperoleh dari membagi frekuensi yang diperoleh dengan jumlah subjek, kemudian dikalikan $100 \%$. Adapun rumusnya sebagai berikut.

$$
P=\frac{F}{N} X 100 \%
$$


Publish by: Library of STKIP PGRI Sumatera Barat

E-ISSN : 2775-5770

Vol. 1 No. 4 (November 2021) (724-732) http://ejournal.stkip-pgri-sumbar.ac.id/index.php/horizon

Keterangan:

$\mathrm{P}=$ Presentase jawaban

$\mathrm{F}=$ Frekuensi Jawaban

$\mathrm{N}$ = Banyaknya Responden

Persentase yang diperoleh pada masing-masing item pernyataan atau pertanyaan, kemudian ditafsirkan berdasarkan kriteria berikut menurut (widyasari, 2015):

\section{a) Kriteria Tingkat Kesulitan Siswa}

Tabel 1. Kreteria Tingkat Kesulitan siswa

\begin{tabular}{ll}
\hline Taraf /Tingkat Kesulitan & Kriteria \\
\hline \multirow{2}{*}{$61 \leq \mathrm{P}<100$} & Sangat \\
$45 \leq \mathrm{P}<61$ & Tinggi \\
$35 \leq \mathrm{P}<45$ & Tinggi \\
$21<\mathrm{P}<35$ & Sedang \\
$0 \leq \mathrm{P}<21$ & Rendah \\
& Sangat \\
\hline
\end{tabular}

Sumber: e-Journal PGSDUniversitas Pendidikan Ganesh

Hasilnya dibandingkan dengan kriteria tingkat kesulitan belajar matematika, kriteria ini digunakan untuk mengetahui tingkat kesulitan yang dialami oleh siswa dalam mempelajari matematika.

b) Kualifikasi Faktor-Faktor Penyebab Kesulitan Belajar Siswa
Tabel 2. Kualifikasi faktor-faktor penyebab kesulitan belajar siswa

\begin{tabular}{ll}
\hline $\begin{array}{c}\text { Taraf / Tingkat } \\
\text { Kesulitan (\%) }\end{array}$ & \multicolumn{1}{c}{ Kriteria } \\
\hline $75 \leq \mathrm{P}<100$ & Sangat \\
$50<\mathrm{P}<75$ & Berpengaruh \\
$25 \leq \mathrm{P}<50$ & Berpengaruh \\
& Cukup \\
$0<\mathrm{P}>25$ & Tidak \\
& Berpengaruh \\
\hline \multicolumn{2}{c}{ Sumber: Zarkasyi, 2015 }
\end{tabular}

Hasilnya dibandingkan dengan Kualifikasi faktor-faktor penyebab kesulitan belajar siswa, Kualifikasi ini digunakan untuk mengetahui faktor faktor yang menjadi penyebab kesulitan yang dialami oleh siswa dalam mempelajari matematika dan hasilnya nanti di analisis beserta dengan hasil wawancara.

2. Wawancara

Wawancara dilakukan untuk mencari tahu kesulitan belajar siswadalam pembelajara matematika dilihat berdasarkan faktor-faktor yang mempengaruhinya. Pertanyaan wawancara yang diberikan disesuaikan dengan jawaban siswa dalam pengisian angket. Sehingga melalui wawancara diharapkan informasi yang diperoleh lebih 


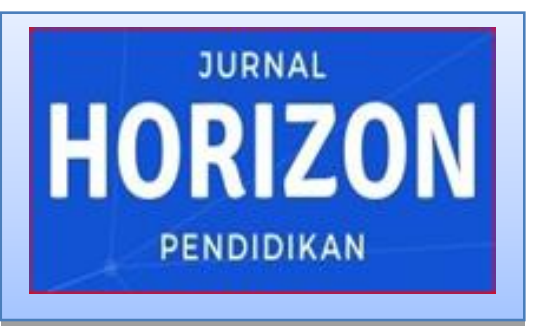

JURNAL HORIZON PENDIDIKAN

Publish by: Library of STKIP PGRI Sumatera Barat

E-ISSN : 2775-5770

Vol. 1 No. 4 (November 2021) (724-732) http://ejournal.stkip-pgri-sumbar.ac.id/index.php/horizon

mendalam dan akurat.Hasil

Dari tabel 3 tampak

wawancara akan dianalisis dan

dicocokan dengan hasil angket untuk mendapatkan faktor-faktor apa saja yang mempengaruhi kesulitan belajar siswa dalam menyelesaikan soal matematika.

Wawancara yang akan
dilaksanakan dengan chat
whatsapp.

\section{HASIL DAN PEMBAHASAN}

a) Data Hasil Penelitian Kesulitan Belajar

Hasil dari angket kesulitan belajar siswa dilihat dari faktorfaktor penyebabnya yang telah diisi oleh 32 siswa, akan diindentifikasi berdasarkan tingkat kesulitan belajar siswa. Diperoleh tingkat kesulitan belajar siswa sebagai berikut:

Tabel 3. Tingkat Kesulitan Belajar Matematika Siswa

\begin{tabular}{|c|c|c|c|}
\hline No & Frekuensi & Persentase & Kriteria \\
\hline 1 & 6 & 18,7 & $\begin{array}{l}\text { Sangat } \\
\text { tinggi }\end{array}$ \\
\hline 2 & 15 & 46,8 & Tinggi \\
\hline 3 & 6 & 18,7 & Sedang \\
\hline 4 & 3 & 9,3 & Rendah \\
\hline 5 & 2 & 6,2 & $\begin{array}{l}\text { Sangat } \\
\text { rendah }\end{array}$ \\
\hline
\end{tabular}

kategori-kategori kesulitan belajar siswa. Kebanyakan siswa mengalami kesulitan belajar terbanyak pada kategori tinggi, hal ini menunjukan banyaknya siswa yang mengalami kesulitan belajar matematika. setelah diperoleh data siswa yang mengalami kesulitan belajar berdasarkan faktor-faktornya akan di analisis menggunakan rumus presentase agar kita dapat mengetahui presentase dari tingkat kesulitan belajar siswa.

b) Data Hasil Faktor Penyebab

Kesulitan Belajar

Hasil angket kesulitan belajar siswa berdasarkan faktorfaktor penyebabnya yang telah diisi oleh siswa akan diidentifikasi berdasarkan ketegori faktor penyebabab kesulitan belajar.

Kesulitan belajar matematika siswa diperoleh skor tertinggi pada faktor intenal dengan indikator kesiapan dengan skor 23,7 kategori sangat berpengaruh dengan 4 item pertanyaan pada indikator 


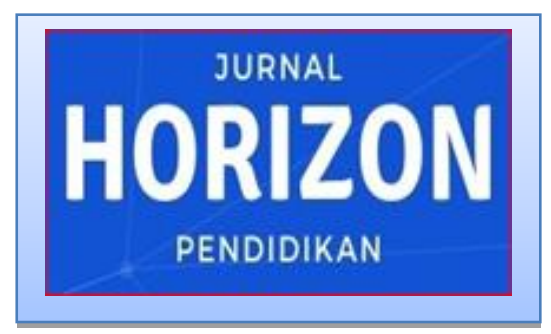

Publish by: Library of STKIP PGRI Sumatera Barat

perhatiaan dengan 2 item

pertanyaan dengan skor 9,5

dengan frekuensi cukup

berpengaruh, pada indikator

minat dengan 4 item pertanyaan dengan skor 17 berpengaruh pada indikator motivasi denagn

2 item pertanyaan derngan skor

16,5 sedangkan skor pada faktor eksternal yaitu dengan indikator keluarga dengan skor 12, pada indikator sekolah terdapat skor 16,5 dan pada indikator masyarakat terdapat skor 12,7 . Berdasarkan hasil data skor tersebut akan dianalisis dengan rumus presentase untuk mengetahui presentase tingkat kesulitan belajar matematika siswa jika dilihat dari faktorfaktor penyebabnya.

\section{KESIMPULAN}

Berdasarkan hasil analisis data penelitian dan pembahasan yang diuraikan, maka peneliti dapat menarik kesimpulan tentang faktor penyebab kesulitan belajar dalam mengikuti mata pelajaran matematika siswa kelas XI IPS 4
E-ISSN : 2775-5770

JURNAL HORIZON PENDIDIKAN

Vol. 1 No. 4 (November 2021) (724-732)

SMA Negeri 2 Sungai Limau, sebagai berikut:

1. Tingkat kesulitan belajar dalam mengikuti mata pelajaran matematika siswa kelas XI IPS 4 SMA Negeri 2 Sungai Limau ditinjau dari faktor-faktor penyebab kesulitan belajar sebesar $18,7 \%$ siswa rata-rata memiliki kesulitan belajar matematika dengan kategori sangat tinggi, sebanyak $46 \%$ siswa rata-rata memiliki kesulitan belajar matematika dengan kategori tinggi, sebanyak $18,7 \%$ siswa rata-rata mengalami kesulitan belajar matematika dengan kategori sedang, sebanyak 9,3\% siswa rata-rata mengalami kesulitan belajar matematika dengan kategori rendah, dan sebanyak $6,2 \%$ siswa rata-rata mengalami kesullitan belaja matematika dengan kategori sangat rendah.

2. Faktor kesulitan belajar dalam mengikuti mata pelajaran matematika siswa kelas XI IPS 4 SMA Negeri 2 Sungai Limau ditinjau dari faktor internal diuraikan sebagai berikut, dalam 
Publish by: Library of STKIP PGRI Sumatera Barat

E-ISSN : 2775-5770

Vol. 1 No. 4 (November 2021) (724-732)

http://ejournal.stkip-pgri-sumbar.ac.id/index.php/horizon

indikator kesiapan dalam belajar sebanyak $71,8 \%$ rata rata kesiapan dalam belajar matematika berpengaruh pada proses pembelajaran, pada indikator motivasi sebanyak $29,6 \%$ siswa rata-rata kurang termotivasi dalam belajar matematika jadi hal ini cukup berpengaruh kepada lancarnya proses pembelajaran, pada indikator minat belajar sebanyak $53 \%$ minat dalam belajar matematika siswa kurang hal cukup berpengaruh dalam proses lancarnya pembelajaran matematika dan indikator kesehatan sebanyak $50,6 \%$ dengan kategori cukup berpengaruh pada proses pembelajaran matematika.

3. Faktor kesulitan belajar dalam mengikuti mata pelajaran matematika siswa kelas XI IPS 4 SMA Negeri 2 Sungai Limau ditinjau dari faktor eksternalnya yang terdiri dari 3 indikator dengan uraian sebagai berikut dalam indikator faktor keluarga dalam belajar sebanyak $37,5 \%$ rata rata faktor keluarga cukup mempengaruhi pembelajaran matematika, pada indikator sekolah sebanyak $51,5 \%$ rata rata siswa pada faktor sekolah hal ini menyakan sangat berpengaruh pada proses pembelajaran matematika dan pada indikator lingkungan masyarakat sebanyak $39,6 \%$ lingkungan masyarakat berpengaruh pada proses pembelajaran matematika siswa.

Berdasarkan simpulan di atas diperoleh faktor internal penyebab kesulitan belajar tertinggi yaitu indikator persiapan dengan presentase $\quad 71,8 \%$ dalam mengikuti pembelajaran matematika secara daring, sedangkan faktor eksternal penyebab kesulitan belajar matematika tertinggi yaitu indikator sekolah yaitu subindikator waktu pembelajran dengan presentse $51,5 \%$. Jadi dapat diambil kesimpulan faktor yang paling berpengaruh yaitu faktor eksternal dengan indikator sekolah yaitu subindikator waktu pembelajaran. 
Publish by: Library of STKIP PGRI Sumatera Barat

Vol. 1 No. 4 (November 2021) (724-732)

http://ejournal.stkip-pgri-sumbar.ac.id/index.php/horizon

\section{DAFTAR PUSTAKA}

Arikunto, S. (2010). Prosedur Penelitian Suatu Pendekatan Praktik (Suharsimi Arikunto (ed.); Edisi Revi). Rineka Cipta.

Fauziah, U. (2017). Analisis Faktor Penyebab Kesulitan Belajar Matamatika Pada Siswa Kelas $X$ SMA Datuk Ribandang. Skripsi.

Slameto. (2010). Belajar dan Faktorfaktor yang Mempengaruhi. PT. Rineka Cipta.

Widyasari, ni made dwi, Gede Meter, G. A. O. N. (2015). Analisis Kesulitan-Kesulitan Belajar Matematika Siswa. E-Journal PGSD Universitas Pendidikan Ganesha, 1. 